\title{
Stability Indicating RP-HPLC Method Development and Validation for simultaneous estimation of Indacaterol and Glycopyrrolate and in Bulk and Pharmaceutical Dosage Form
}

\author{
Navya Vutukuri ${ }^{1}$, M. Ajitha ${ }^{2}$ \\ ${ }^{1}$ M. Pharmacy Scholar, Department of Pharmaceutical Analysis, Institute of Science and \\ Technology, JNTUH, Hyderabad \\ ${ }^{2}$ Professor \& Head, Deputy Director of Academic Audit Cell - JNTUH \& OIE, Center for \\ Pharmaceutical Sciences, JNTUH, Hyderabad
}

Received: 21-10-2021 / Revised Accepted: 26-11-2021 / Published: 02-01-2022

\begin{abstract}
A simple, Accurate, precise method was developed for the simultaneous estimation of the Indacaterol and Glycopyrrolate in API and pharmaceutical dosage form. Chromatogram was run through Agilent $\mathrm{C} 18(150 \times 4.6 \mathrm{~mm}, 5 \mu)$. Mobile phase containing Buffer $0.01 \mathrm{~N}$ $\mathrm{KH}_{2} \mathrm{PO}_{4}$ : Acetonitrile taken in the ratio 50:50 was pumped through column at a flow rate of $1.0 \mathrm{ml} / \mathrm{min}$. Buffer used in this method was $0.01 \mathrm{~N} \mathrm{KH}_{2} \mathrm{PO}_{4}$ buffer. Retention time of Indacaterol and Glycopyrrolate were found to be $2.285 \mathrm{~min}$ and $2.992 \mathrm{~min}$. \%RSD of the Indacaterol and Glycopyrrolate were and found to be 0.3 and 0.6 respectively. \%Recovery was obtained as $100.73 \%$ and $99.54 \%$ for Indacaterol and Glycopyrrolate, respectively. LOD, LOQ values obtained from regression equations of Indacaterol and Glycopyrrolate were 0.45, 1.36 and $0.19,0.59$ respectively. Regression equation of Indacaterol is $\mathrm{y}=17065 \mathrm{x}+3029$, and $y=16589 x+4026$, of Glycopyrrolate. Retention times were decreased and that run time was decreased, so the method developed was simple and economical that can be adopted in regular Quality control test in Industries.
\end{abstract}

Key Words: Indacaterol, Glycopyrrolate, RP-HPLC

\section{INTRODUCTION}

Indacaterol is a novel, Ultra-Long-Acting, rapid onset $\beta$ (2)-Adrenoceptor agonist developed for Novartis for the once-daily management of Asthma and Chronic Obstructive Pulmonary Disease. Glycopyrronium (as the bromide salt glycopyrrolate) is a synthetic anticholinergic agent with a quaternary ammonium structure. A strong muscarinic antagonist used as an antispasmodic in certain gastrointestinal tract disorders and with some anaesthetics to suppress salivation. The FDA approved glycopyrrolate as a stand-alone treatment for chronic obstructive pulmonary disease (COPD). Literature survey revealed that there were few analytical methods reported for Indacaterol and Glycopyrrolate in RP-HPLC. However, an

Address for Correspondence: Navya Vutukuri, M. Pharmacy Scholar, Department of Pharmaceutical Analysis, Institute of Science and Technology, JNTUH, Hyderabad.

How to Cite this Article: Navya Vutukuri, M. Ajitha. Stability Indicating RP-HPLC Method Development and Validation for simultaneous estimation of Indacaterol and Glycopyrrolate and in Bulk and Pharmaceutical Dosage Form. World J Pharm Sci 2022; 10(01): 74-81; https://doi.org/10.54037/WJPS.2022.100107 
extensive literature search didn't reveal any estimation method for Indacaterol and Glycopyrrolate in API \& Pharmaceutical dosage form. Therefore, an attempt has been made to develop and validate simple, precise, accurate economical RP-HPLC method as per ICH guidelines for the estimation of Indacaterol and Glycopyrrolate in Bulk and Pharmaceutical dosage form.

\section{MATERIALS AND METHOD}

Indacaterol and Glycopyrrolate pure drugs (API), Combination Indacaterol and Glycopyrrolate bromide inhaler (Sequadra), Distilled water, Acetonitrile, Phosphate buffer, Methanol, Potassium dihydrogen ortho phosphate buffer, Ortho-phosphoric acid. All the above chemicals and solvents are from Rankem.

Instruments and Chromatographic Conditions Electronics Balance-Denver, $\mathrm{pH}$ meter -BVK enterprises, India, Ultrasonicator-BVK enterprises, WATERS HPLC 2695 SYSTEM equipped with quaternary pumps, Photo Diode Array detector and Auto sampler integrated with Empower 2 Software. UV-VIS spectrophotometer PG Instruments T60 with special bandwidth of $2 \mathrm{~mm}$ and $10 \mathrm{~mm}$ and matched quartz cells integrated with UV win 6 Software was used for measuring absorbances of Indacaterol and Glycopyrrolate solutions.

\section{Methods}

Diluent: Based up on the solubility of the drugs, diluent was selected, Acetonitrile and Water taken in the ratio of 50:50.

\section{Buffer:}

0.1\% OPA Buffer: $1 \mathrm{ml}$ of ortho phosphoric acid was diluted to $1000 \mathrm{ml}$ with HPLC grade water.

0.01N Potassium dihyrogen Ortho phosphate $\left(\mathrm{KH}_{2} \mathrm{PO}_{4}\right)$ : Accurately weighed $1.36 \mathrm{gm}$ of Potassium dihyrogen Ortho phosphate $\left(\mathrm{KH}_{2} \mathrm{PO}_{4}\right)$ in a $1000 \mathrm{ml}$ of Volumetric flask add about $900 \mathrm{ml}$ of milli-Q water added and degas to sonicate and finally make up the volume with water then added $1 \mathrm{ml}$ of Triethylamine then $\mathrm{PH}$ adjusted to 3.5 with dil. Orthophosphoric

acid solution.

Standard stock solution Preparation: Accurately weighed $27.5 \mathrm{mg}$ of Indacaterol, $12.5 \mathrm{mg}$ of Glycopyrrolate and transferred to $50 \mathrm{ml}$ volumetric flask and 3/4th of diluents was added to this flask and sonicated for 10 minutes. Flask were made up with diluents and labeled as Standard stock solution. $(550 \mu \mathrm{g} / \mathrm{ml}$ of Indacaterol and $250 \mu \mathrm{g} / \mathrm{ml}$ of Glycopyrrolate)
Standard working solution Preparation: $1 \mathrm{ml}$ from each Standard stock solution was pipetted out and taken into a $10 \mathrm{ml}$ volumetric flask and made up with diluent. $(55 \mu \mathrm{g} / \mathrm{ml}$ of Indacaterol and $25 \mu \mathrm{g} / \mathrm{ml}$ of Glycopyrrolate).

Sample stock solution Preparation: The contents of nasal spray delivered by 50 actuations $(110 \mathrm{mcg}$ \&55 mcg each) were collected in $100 \mathrm{ml}$ volumetric flask. Then $20 \mathrm{ml}$ acetonitrile was added, sonicated for $25 \mathrm{~min}$ and made up to mark to yield $1100 \& 500 \mu \mathrm{g} / \mathrm{ml}$. It was centrifuged for $20 \mathrm{~min}$. Then the supernatant was collected and filtered using $0.45 \mu \mathrm{m}$ filters using (Millipore, Milford, PVDF)

Sample working solution preparation: $0.5 \mathrm{ml}$ from sample stock solution was pipetted out and taken into a $10 \mathrm{ml}$ volumetric flask and made up with diluent. $(55 \mu \mathrm{g} / \mathrm{ml}$ of Indacaterol and $25 \mu \mathrm{g} / \mathrm{ml}$ of Glycopyrrolate).

\section{Method Validation}

As per ICH guidelines the method was validated and the parameters like Linearity, Specificity, Accuracy, Precision, Limit of Detection (LOD) and Limit of Quantitation (LOQ) were assessed.

Specificity: Checking of the interference in the optimized method. We should not find interfering peaks in blank and placebo at retention times of these drugs in this method. So this method was said to be specific.

Linearity: Accurately weighed $27.5 \mathrm{mg}$ of Indacaterol, $12.5 \mathrm{mg}$ of Glycopyrrolate and transferred to $50 \mathrm{ml}$ volumetric flask and 3/4th of diluents was added to these flask and sonicated for 10 minutes. Flask were made up with diluents and labeled as Standard stock solution. $(550 \mu \mathrm{g} / \mathrm{ml}$ of Indacaterol and $250 \mu \mathrm{g} / \mathrm{ml}$ of Glycopyrrolate). Stock solutions of Indacaterol and Glycopyrrolate is taken into 6 different volumetric flasks and diluted to $10 \mathrm{ml}$ with diluents. Linearity solutions are prepared such that $0.25,0.5,0.75,1,1.25$, $1.5 \mathrm{ml}$.

Accuracy: Accurately weighed $27.5 \mathrm{mg}$ of Indacaterol, $12.5 \mathrm{mg}$ of Glycopyrrolate and transferred to $50 \mathrm{ml}$ volumetric flask and 3/4th of diluents was added to these flasks and sonicated for 10 minutes. Flask were made up with diluents and labeled as Standard stock solution. $(550 \mu \mathrm{g} / \mathrm{ml}$ of Indacaterol and $250 \mu \mathrm{g} / \mathrm{ml}$ of Glycopyrrolate)

Preparation of $50 \%$ Spiked Solution: $0.5 \mathrm{ml}$ of sample stock solution was taken into a $10 \mathrm{ml}$ volumetric flask, to that $1.0 \mathrm{ml}$ from each standard 
stock solution was pipetted out, and made up to the mark with diluent.

Preparation of $100 \%$ Spiked Solution: $1.0 \mathrm{ml}$ of sample stock solution was taken into a $10 \mathrm{ml}$ volumetric flask, to that $1.0 \mathrm{ml}$ from each standard stock solution was pipetted out, and made up to the mark with diluent.

Preparation of $150 \%$ Spiked Solution: $1.5 \mathrm{ml}$ of sample stock solution was taken into a $10 \mathrm{ml}$ volumetric flask, to that $1.0 \mathrm{ml}$ from each standard stock solution was pipetted out, and made up to the mark with diluent.

Robustness: Small deliberate changes in method like Flow rate, mobile phase ratio, and temperature are made but there were no recognized change in the result and are within range as per ICH Guide lines. Robustness conditions like Flow minus $(0.9 \mathrm{ml} / \mathrm{min})$, Flow plus $(1.1 \mathrm{ml} / \mathrm{min})$, mobile phase minus, mobile phase plus, temperature minus $\left(25^{\circ} \mathrm{C}\right)$ and temperature plus $\left(35^{\circ} \mathrm{C}\right)$ was maintained and samples were injected in duplicate manner. System suitability parameters were not much effected and all the parameters were passed. \%RSD was within the limit.

LOD: $0.25 \mathrm{ml}$ each from two standard stock solutions was pipetted out and transferred to two separate $10 \mathrm{ml}$ volumetric flasks and made up with diluents. From the above solutions $0.1 \mathrm{ml}$ each of Indacaterol, Glycopyrrolate, solutions respectively were transferred to $10 \mathrm{ml}$ volumetric flasks and made up with the same diluents

LOQ: $0.25 \mathrm{ml}$ each from two standard stock solutions was pipetted out and transferred to two separate $10 \mathrm{ml}$ volumetric flask and made up with diluent. From the above solutions $0.3 \mathrm{ml}$ each of Indacaterol, Glycopyrrolate solutions respectively were transferred to $10 \mathrm{ml}$ volumetric flasks and made up with the same diluent.

System suitability parameters: The system suitability parameters were determined by preparing standard solutions of Indacaterol (55ppm) and Glycopyrrolate $(25 \mathrm{ppm})$ and the solutions were injected six times and the parameters like peak tailing, resolution and USP plate count were determined. The \% RSD for the area of six standard injections results should not be more than $2 \%$.

Assay: (Sequadra) bearing the label claim Indacaterol $110 \mathrm{mcg}$, Glycopyrrolate $50 \mathrm{mcg}$. Assay was performed with the above formulation. by injecting sample corresponding to equivalent weight into HPLC system.

\section{RESULTS \& DISCUSSIONS}

Optimization of Chromatographic Conditions: To develop and establish a suitable RP-HPLC method for estimation of Indacaterol and Glycopyrrolate in bulk and tablet dosage forms, different preliminary tests were performed and different chromatographic conditions were tested and optimized chromatographic conditions were developed which were given in Table-1.The final analysis was performed by using $0.01 \mathrm{~N}$ Potassium dihyrogen Ortho phosphate : Acetonitrile (50:50) at a flow rate of $1.0 \mathrm{ml} / \mathrm{min}$, samples were analyzed at $210 \mathrm{~nm}$ detector wave length and at an injection volume of $10 \mu \mathrm{L}$ using Agilent C18 (4.6 x 150mm, $5 \mu \mathrm{m})$ with run time of $5 \mathrm{~min}$. The proposed method was optimized to give sharp peak and both peaks have good resolution, tailing factor, theoretical plate count and resolution for Indacaterol and Glycopyrrolate, the optimized chromatogram was obtained as shown in (Figure- 3 ).

Linearity: Linearity was established for six linear concentrations of Indacaterol $(13.75-82.5 \mu \mathrm{g} / \mathrm{ml})$ and Glycopyrrolate $(6.25-37.5 \mu \mathrm{g} / \mathrm{ml})$ were injected in a duplicate manners Average areas were determined and linearity equations obtained for Indacaterol was $\mathrm{y}=17065 \mathrm{x}+3029$. and of Glycopyrrolate was $\mathrm{y}=16589 \mathrm{x}+4026$ respectively. Correlation coefficient obtained was 0.999 for the two drugs. The Linearity calibration curves were plotted as shown in (Figure-4, 5).

Specificity: Retention times of Indacaterol and Glycopyrrolate are $2.285 \mathrm{~min}$ and $2.992 \mathrm{~min}$ where no interfering peaks in blank and placebo were found in this method. So, this method holds its specificity.

Accuracy: Three levels of Accuracy samples 50\%, $100 \%, 150 \%$ were prepared and triplicates of injections were given for each level of accuracy and mean \% Recovery was obtained as $100.73 \%$ and $99.54 \%$ for Indacaterol and Glycopyrrolate.

Precision: Intraday precision (Repeatability) with $\%$ RSD calculated from the corresponding peaks obtained by injecting six times a known concentration of both Indacaterol and Glycopyrrolate was obtained as $0.5 \%$ and the $\%$ RSD for Interday precision was obtained as $0.4 \%$ and $0.8 \%$ for Indacaterol and Glycopyrrolate respectively. Low \% RSD values indicates that the method developed was precise as shown in table.

LOD \& LOQ: The LOD and LOQ values were evaluated based on Relative standard deviation (\%RSD) of response and slope of the calibration curve of the two drugs. The detection limit (LOD) value was obtained as $0.45,0.19$ for Indacaterol 
and Glycopyrrolate respectively. Quantitation limit (LOQ) was found to be $1.36 \& 0.59$ for Indacaterol and Glycopyrrolate respectively as given in (Table4).

Robustness: Robustness conditions like Flow minus $(0.9 \mathrm{ml} / \mathrm{min})$, Flow plus $(1.1 \mathrm{ml} / \mathrm{min})$, mobile phase minus $(55: 45)$, mobile phase plus (45:55), temperature minus $\left(25^{\circ} \mathrm{C}\right)$ and temperature plus $\left(35^{\circ} \mathrm{C}\right)$ were maintained and samples were injected in duplicate manner (Table-5). System suitability parameters were not much affected and all the parameters were passed. \%RSD was within the limit (Table -6).

Assay: Indacaterol and Glycopyrrolate pure drug (API) was obtained from Spectrum Pharma research solutions, combination dosage form (Sequadra) bearing the label claim Indacaterol $110 \mathrm{mcg}$, Glycopyrrolate 50mcg. Assay was performed with the above formulation. Average \% Assay obtained for Indacaterol and Glycopyrrolate was $100.57 \%$ and $99.85 \%$ and the chromatogram of standard drugs and pharmaceutical dosage forms were shown in (Figure-6,7) respectively.

Degradation Studies: Degradation studies were performed with the formulation and the degraded samples were injected. Assay of the injected samples was calculated and all the samples passed the limits of degradation (Table 8).

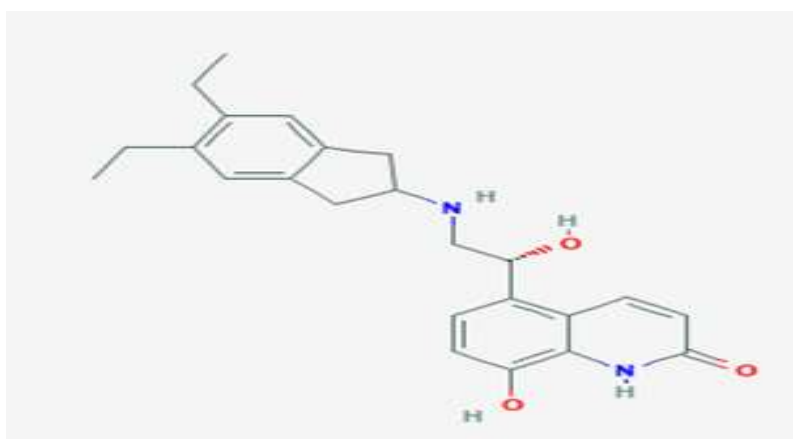

Figure-1: Chemical Structure of Indacaterol

\section{Conclusion}

Chromatographic conditions used are stationary

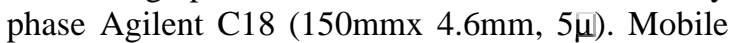
phase is $0.01 \mathrm{~N}$ Potassium dihyrogen Ortho phosphate $\left(\mathrm{KH}_{2} \mathrm{PO}_{4}\right)$ : Acetonitrile in the ratio of $50: 50$ and flow rate was maintained at $1.0 \mathrm{ml} / \mathrm{min}$, detection wave length was $210 \mathrm{~nm}$, column temperature was set to $30^{\circ} \mathrm{C}$. Conditions were finalized as optimized method. System suitability parameters were studied by injecting the standard six times and results were well under the acceptance criteria. Linearity study was carried out between $25 \%$ to $150 \%$ levels, $\mathrm{R}^{2}$ values for Indacaterol and Glycopyrrolate were found to be 0.999 and 0.999 respectively. Precision was found to be $0.4 \%$ and $0.8 \%$ for Indacaterol and Glycopyrrolate respectively. LOD and LOQ are $0.45 \& 0.19$ and $1.36 \& 0.59$ for Indacaterol and Glycopyrrolate respectively. By using above method assay of marketed formulation was carried out $100.57 \%$ and $99.85 \%$ for Indacaterol and Glycopyrrolate respectively. Degradation studies of Indacaterol and Glycopyrrolate were done, in all condition's purity threshold was more than purity angle and within the acceptable range. Retention times are decreased and that run time was decreased so the method developed was simple and economical that can be adopted in regular Quality control test in Industries.

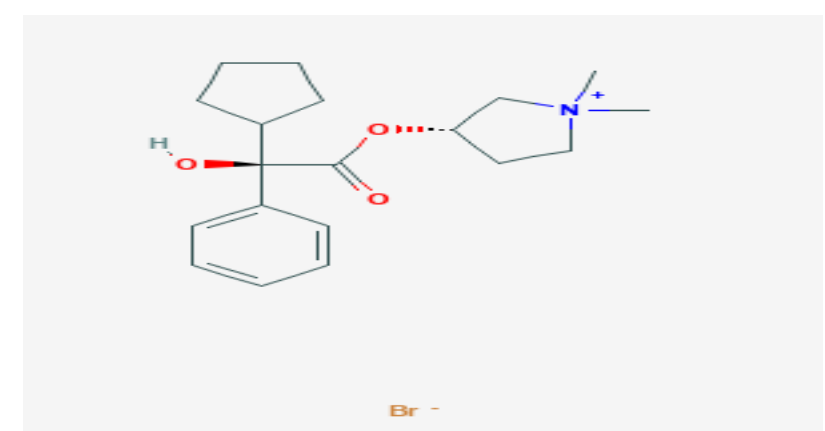

Figure-2: Chemical Structure of Glycopyrrolate

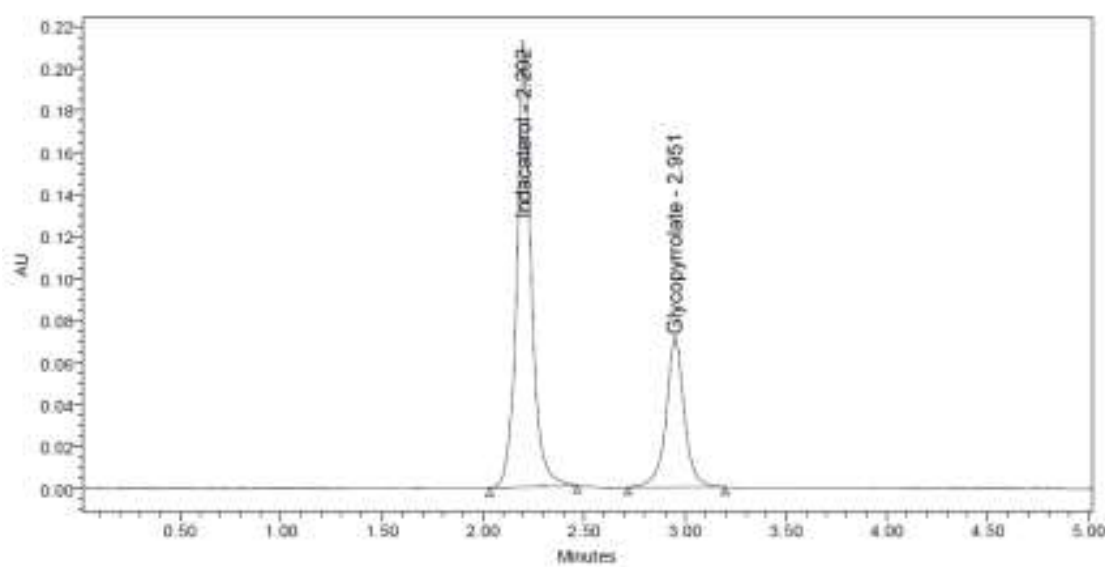

Figure-3: Optimized Chromatogram of Indacaterol and Glycopyrrolate 
Navya and Ajitha, World J Pharm Sci 2022; 10(01): 74-81

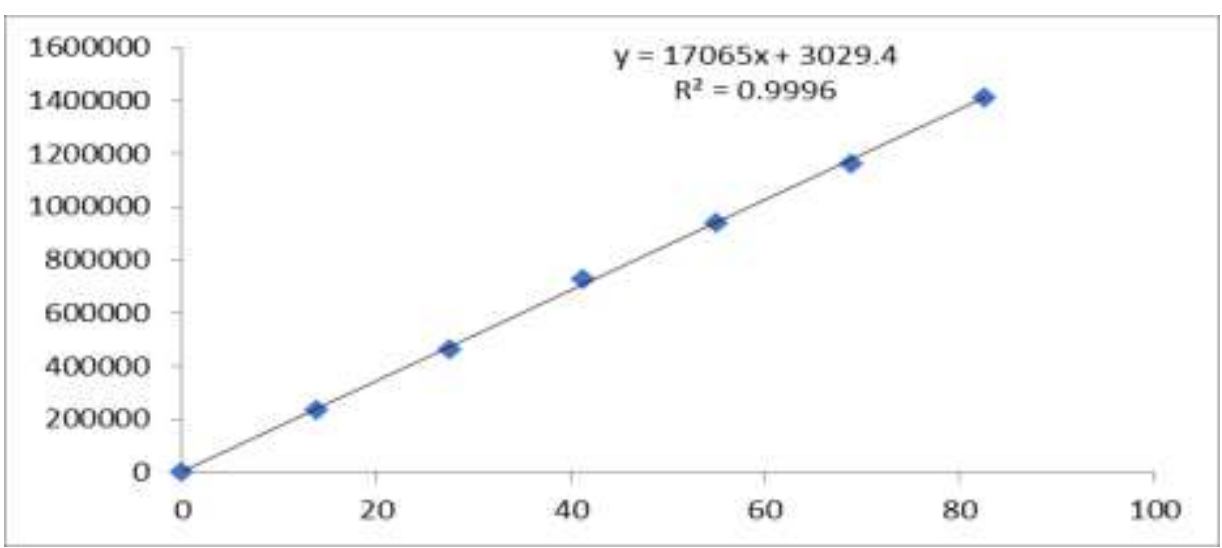

Figure -4: Linearity curve of Indacaterol

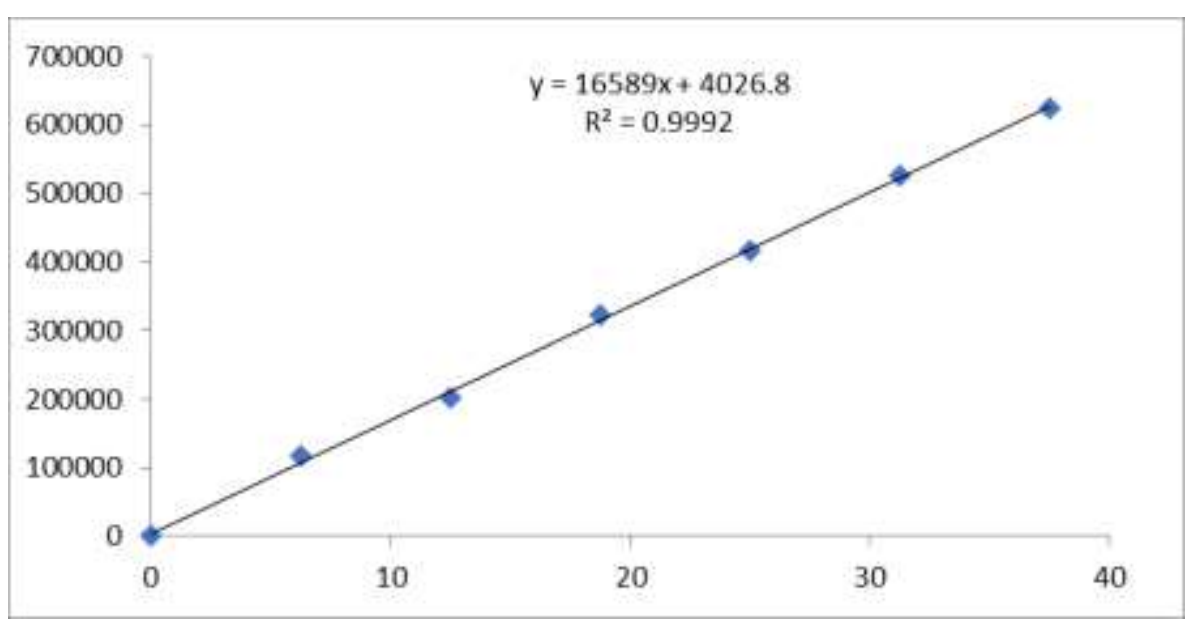

Figure -5: Linearity curve of Glycopyrrolate

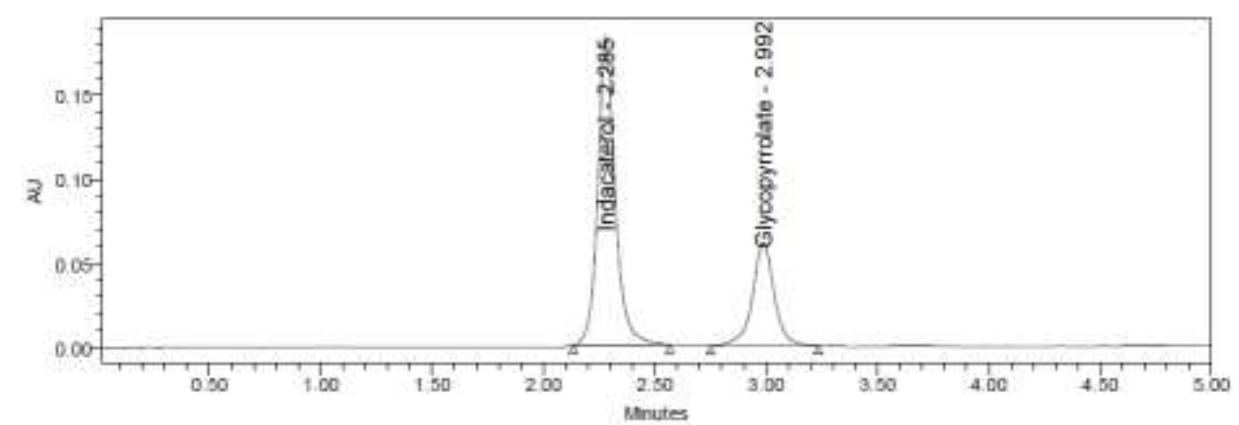

Figure -6: Standard Chromatogram of Indacaterol and Glycopyrrolate

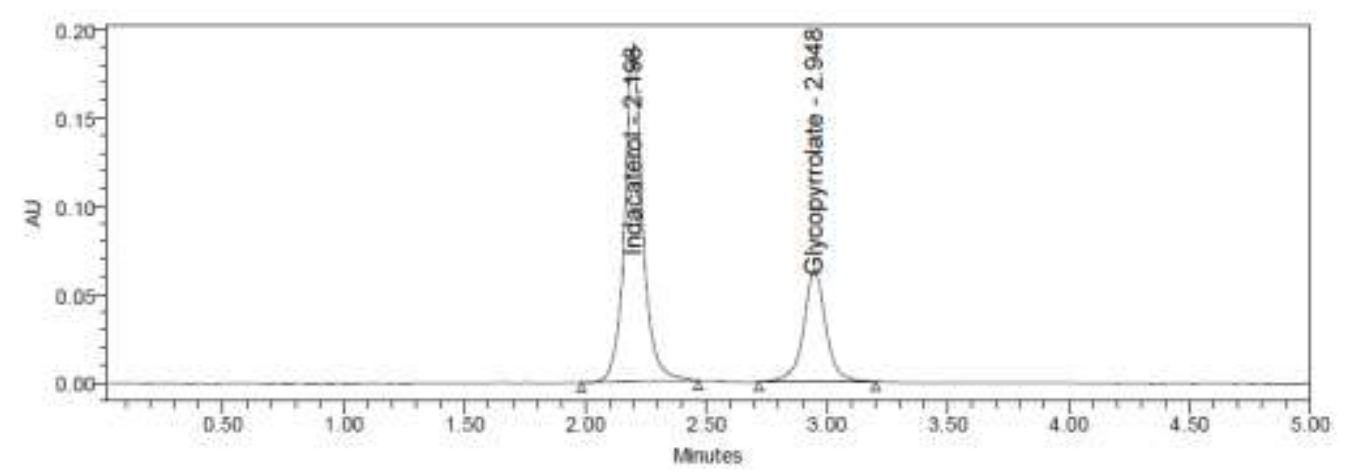

Figure -7: Sample Chromatogram of Indacaterol and Glycopyrrolate 
Table 1: Optimized Chromatographic Conditions

\begin{tabular}{|l|l|}
\hline Parameter & Conditions \\
\hline RP-HPLC & $\begin{array}{l}\text { WATERS HPLC SYSTEM equipped with quaternary pumps with } \\
\text { PDA detector }\end{array}$ \\
\hline Mobile Phase & $0.01 \mathrm{~N} \mathrm{KH}_{2} \mathrm{PO}_{4}:$ Acetonitrile(50:50) \\
\hline Flow rate & $1.0 \mathrm{ml} / \mathrm{min}$ \\
\hline Column & Agilent C18(4.6x150mm,5 $\mu \mathrm{m})$ \\
\hline Injection Volume & $10 \mu \mathrm{L}$ \\
\hline Run Time & $5 \mathrm{~min}$ \\
\hline Diluent & Water and Acetonitrile in ratio 50:50 \\
\hline Retention Time & Indacaterol - 2.285 min and Glycopyrrolate - 2.992 min \\
\hline Theoretical Plates & Indacaterol -4553, Glycopyrrolate - 5050 \\
\hline
\end{tabular}

Table-2: Precision Results of Indacaterol and Glycopyrrolate

\begin{tabular}{|l|l|l|l|l|}
\hline \multirow{2}{*}{ S.no } & \multicolumn{2}{|l|}{ Repeatability (Intraday) } & Intermediate Precision (Day-Day Precision) \\
\cline { 2 - 5 } & Indacaterol & Glycopyrrolate & Indacaterol & Glycopyrrolate \\
\hline $\mathbf{1}$ & 935494 & 417178 & 942577 & 422446 \\
\hline $\mathbf{2}$ & 940812 & 419887 & 933513 & 418150 \\
\hline $\mathbf{3}$ & 947658 & 423602 & 935320 & 413101 \\
\hline $\mathbf{4}$ & 945698 & 421186 & 930494 & 414178 \\
\hline $\mathbf{5}$ & 942712 & 419832 & 936192 & 419186 \\
\hline $\mathbf{6}$ & 936843 & 420892 & 935698 & 415908 \\
\hline mean & 941536 & 420430 & 935632 & 417162 \\
\hline S.D & 4800.8 & 2101.2 & 3988.4 & 3463.0 \\
\hline \%RSD & 0.5 & 0.5 & 0.4 & 0.8 \\
\hline
\end{tabular}

Table-3: Accuracy results of Indacaterol (Drug 1) and Glycopyrrolate ( Drug 2):

\begin{tabular}{|c|c|c|c|c|c|c|c|c|}
\hline \multirow[t]{2}{*}{ \%Level } & \multicolumn{2}{|c|}{ Amount Spiked $(\mu \mathrm{g} / \mathrm{ml})$} & \multicolumn{2}{|c|}{$\begin{array}{l}\text { Amount } \\
\operatorname{Recovery}(\mu \mathrm{g} / \mathrm{ml})\end{array}$} & \multicolumn{2}{|c|}{ \% Recover } & \multicolumn{2}{|c|}{ Mean \% Recovery } \\
\hline & Drug 1 & Drug 2 & Drug 1 & Drug 2 & Drug 1 & Drug 2 & Drug 1 & Drug 2 \\
\hline \multirow{3}{*}{$50 \%$} & 27.5 & 12.5 & 27.88 & 12.43 & 101.36 & 99.41 & \multirow{10}{*}{$100.73 \%$} & \multirow{10}{*}{$99.54 \%$} \\
\hline & 27.5 & 12.5 & 27.42 & 12.45 & 99.70 & 99.64 & & \\
\hline & 27.5 & 12.5 & 27.72 & 12.40 & 100.79 & 99.24 & & \\
\hline \multirow{4}{*}{$100 \%$} & 8 & 25 & 55.70 & 24.88 & 101.27 & 99.53 & & \\
\hline & 55 & 25 & 55.70 & 24.88 & 101.47 & 99.53 & & \\
\hline & 55 & 25 & 55.81 & 24.98 & 101.12 & 99.90 & & \\
\hline & 55 & 25 & 55.62 & 25.00 & 100.06 & 100.00 & & \\
\hline \multirow{3}{*}{$150 \%$} & 82.5 & 37.5 & 82.55 & 37.20 & 100.00 & 99.21 & & \\
\hline & 82.5 & 37.5 & 82.50 & 37.20 & 100.84 & 99.21 & & \\
\hline & 82.5 & 37.5 & 83.19 & 37.41 & 101.36 & 99.75 & & \\
\hline
\end{tabular}

Table-4: LOD and LOQ values of Indacaterol and Glycopyrrolate

\begin{tabular}{|l|l|l|}
\hline Molecule & LOD & LOQ \\
\hline Indacaterol & 0.45 & 1.36 \\
\hline Glycopyrrolate & 0.19 & 0.59 \\
\hline
\end{tabular}


Table-5 Robustness Data of Indacaterol and Glycopyrrolate

\begin{tabular}{|l|l|l|l|}
\hline S.no & Condition & \%RSD of Indacaterol & \%RSD of Glycopyrrolate \\
\hline $\mathbf{1}$ & Flow rate (-) $0.9 \mathrm{ml} / \mathrm{min}$ & 0.1 & 1.1 \\
\hline $\mathbf{2}$ & Flow rate (+) $1.1 \mathrm{ml} / \mathrm{min}$ & 0.3 & 0.7 \\
\hline $\mathbf{3}$ & Mobile phase (-) 55B:45A & 0.2 & 0.5 \\
\hline $\mathbf{4}$ & Mobile phase (+) 45B:55A & 0.3 & 0.8 \\
\hline $\mathbf{5}$ & Temperature (-) $25^{\circ} \mathrm{C}$ & 0.6 & 0.8 \\
\hline $\mathbf{6}$ & Temperature (+) $35^{\circ} \mathrm{C}$ & 0.1 & 0.2 \\
\hline
\end{tabular}

Table-6 System Suitability Parameters for Indacaterol and Glycopyrrolate

\begin{tabular}{|l|l|l|l|l|l|l|l|}
\hline S no & \multicolumn{2}{|l|}{ Indacaterol } & \multicolumn{2}{l|}{ Glycopyrrolate } \\
\hline Inj & RT(min) & $\begin{array}{l}\text { USP Plate } \\
\text { Count }\end{array}$ & Inj & RT(min) & $\begin{array}{l}\text { USP Plate } \\
\text { Count }\end{array}$ & Inj & RT(min) \\
\hline 1 & 2.189 & 4783 & 1 & 2.189 & 4783 & 1 & 2.189 \\
\hline 2 & 2.190 & 4628 & 2 & 2.190 & 4628 & 2 & 2.190 \\
\hline 3 & 2.201 & 5122 & 3 & 2.201 & 5122 & 3 & 2.201 \\
\hline 4 & 2.202 & 4900 & 4 & 2.202 & 4900 & 4 & 2.202 \\
\hline 5 & 2.204 & 4736 & 5 & 2.204 & 4736 & 5 & 2.204 \\
\hline 6 & 2.285 & 4553 & 6 & 2.285 & 4553 & 6 & 2.285 \\
\hline
\end{tabular}

Table-7 Assay Results of Indacaterol and Glycopyrrolate

\begin{tabular}{|l|l|l|}
\hline S.no & \% Assay Indacaterol & \% Assay Glycopyrrolate \\
\hline $\mathbf{1}$ & 99.92 & 100.27 \\
\hline $\mathbf{2}$ & 100.49 & 100.92 \\
\hline $\mathbf{3}$ & 101.22 & 101.81 \\
\hline $\mathbf{4}$ & 101.01 & 101.23 \\
\hline $\mathbf{5}$ & 100.69 & 100.91 \\
\hline $\mathbf{6}$ & 100.07 & 101.16 \\
\hline Avg & 100.57 & 101.05 \\
\hline SD & 0.51 & 0.5 \\
\hline \%RSD & 0.5 & 0.5 \\
\hline
\end{tabular}

Table-8 Degradation Data for Indacaterol and Glycopyrrolate

\begin{tabular}{|l|l|l|l|l|}
\hline \multirow{2}{*}{$\begin{array}{l}\text { Type } \\
\text { Degradation }\end{array}$} & Indacaterol & Glycopyrrolate \\
\cline { 2 - 5 } & \% Degraded & \% Recorded & \% Degraded & \% Recorded \\
\hline Acid & 94.16 & 5.84 & 94.30 & 5.70 \\
\hline Alkali & 95.87 & 4.13 & 95.91 & 4.09 \\
\hline Oxidation & 95.88 & 4.12 & 95.48 & 4.52 \\
\hline Thermal & 98.10 & 1.90 & 96.54 & 3.46 \\
\hline UV & 99.36 & 0.64 & 99.09 & 0.91 \\
\hline Water & 99.71 & 0.29 & 99.33 & 0.67 \\
\hline
\end{tabular}

\section{REFERENCES}

1. B.K Sharma, Instrumental methods of chemical analysis, Introduction to analytical chemistry, $23^{\text {rd }}$ Edition Goel publication, Meerut, (2007)

2. Lindholm.J, Development and Validation of HPLC Method for Analytical and Preparative purpose. Acta Universitatis Upsaliensis, pg . 13-14, (2004). 
3. Rashmin, An introduction to analytical Method Development for Pharmaceutical formulations. Indoglobal Journal of Pharmaceutical Sciences , Vol.2, Issue 2, Pg 191-196 (2012).

4. Malvia R, Bansal V , Pal O.P and Sharma P.K. A Review of High Performance Liquid Chromatography. Journal of Global Pharma technology (2010)

5. Douglas A Skoog, F. James Holler, Timothy A. Niemen, Principles of Instrumental Analysis Pg 725760.

6. Dr.S. Ravi Shankar, Text book of Pharmaceutical analysis, Fourth edition, Pg 13.1-13.2

7. David G.Watson. Pharmaceutical Analysis, A text book for Pharmacy students and Pharmaceutical Chemists. Harcourt Publishers Limited; 2nd Ed., Pg 221-232.

8. Remingtonn's The Sciences and Practise of Pharmacy, 20th Edition (2000)

9. Connors Ka. A Textbook of Pharmaceutical Analysis, Wiley intersciences Inc; Delhi, 3rd Ed, Pg 373421, (1994)

10. Gurdeep R.Chatwal, Sham K .Anand, Instrumental Methods of Chemical Analysis , Pg 2.566-2.638 (2007) 